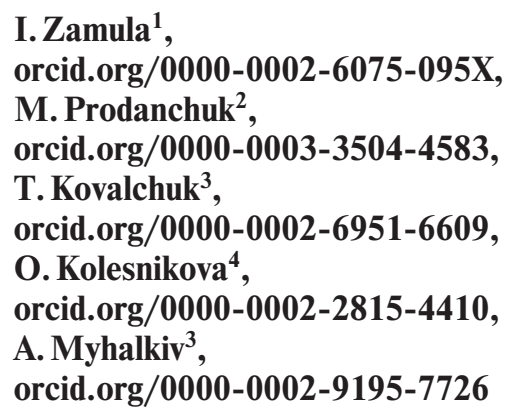

1 - Zhytomyr Polytechnic State University, Zhytomyr, Ukraine, e-mail: zamula@ztu.edu.ua

2 - National Scientific Centre "Institute of Agrarian Economics", Kyiv, Ukraine

3 - Yuriy Fedkovych Chernivtsi National University, Chernivtsi, Ukraine

4 - National University of Life and Environmental Sciences of Ukraine, Kyiv, Ukraine

\title{
INDICATORS OF ECOLOGICAL CONDITION OF NATURAL RESOURCES IN INTEGRATED REPORTING OF THE ENTERPRISE
}

Purpose. The research is aimed at developing a model of integrated reporting which will assess the impact of the enterprise on condition of natural resources and meet the information requests of stakeholders at the micro and macro levels.

Methodology. The fundamental provisions of modern economic theory, accounting theory and economic analysis, scientific developments of national and foreign scientists on non-financial reporting, greening and rationalization of environmental management are the theoretical and methodological basis of the study. To achieve the goal, the following research methods were used: abstract-logical, complex-system approach in the study on the essence of non-financial reporting and identifying its features; cause-and-effect relations - when developing a list of indicators of non-financial reporting on the environmental condition of natural resources in order to increase the relevance of information.

Findings. The structure and content of integrated reporting are proposed in terms of natural resources and their environmental condition, the result of which is reliable, clear and comparable information that will provide a comprehensive analysis of the enterprise and the development of balanced management and control decisions. In the process of integration, non-financial reporting will be complemented by a number of financial indicators that will be compatible with each other, which will help to ensure the high-quality decisions. The proposed integrated reporting will not violate legal rights, commercial obligations, privacy of business owners and will create favorable conditions for effective management of natural resources and their environmental condition.

Originality. The result of the study is a developed scientific and methodological approach to the implementation of integrated reporting of agrarian enterprises in practice. The integration of financial and non-financial reporting on natural resources and their environmental position will create a unified information base for the management of natural capital and the activities of enterprises.

Practical value. Implementation of the proposals will allow: at the level of business entities - forming timely, reliable and adequate to the needs of management information on environmental activities of the enterprise, which will be the basis for balanced management decisions in regulating environmental impact and ensure rational use of natural resources as a basis of national wealth of Ukraine; at the state level - receiving reliable consolidated statistical information that will ensure the validity of state environmental policy, increase the interest and confidence of external users in information about the activities of national enterprises considering their impact on natural resources, restore ecological and economic balance in the country.

Keywords: integrated reporting, non-financial information, natural resources management, ecological responsibility, social responsibility of business

Introduction. Quality information is a key element of the system of sustainable development of society. One of the main principles of the Sustainable Development Program Documents within the framework of the Global Environment Partnership is to reduce the information gap and expand access to information in the decision-making and implementation process. The current global environmental crisis, which is progressing dynamically, requires considerable attention and measures to overcome it.

The current state of management of natural resources used by enterprises requires reconsideration of conceptual issues for the formation of the environmental component of integrated reporting, based on the needs of users of information at micro and macro levels, in order to preserve natural resources and achieve sustainable development.

Land is a key natural resource for Ukraine. According to the State Land Cadastre, the area of agricultural land in Ukraine is approximately 42 million hectares ( $2 / 3$ of the territory). Ukraine, among other European countries, has the most powerful land resource potential, where land capital is up to $6 \%$ (60.3 million hectares) of the entire territory of Europe. The total area of agricultural land is $70.9 \%$ (42.8 million hect-

(C) Zamula I., Prodanchuk M., Kovalchuk T., Kolesnikova O., Myhalkiv A., 2020 ares) of the entire territory of our country. This makes it possible for Ukraine to provide food to 250-320 million people [1].

Land resources management causes the emergence of additional requirements for the information content in reporting of business entities [2]. Management requires a reorientation of management processes to ensure the growth of the value of the business entity, which directly affects the need to expand the scope of information support. After all, for the investor not only the result of economic activity is important, but also the opportunity to increase the value of business in the future, in particular through natural resources [3]. Therefore, today the participants of the natural resources market have a need for new information data generated in both financial and non-financial indicators.

Literature review. The work is devoted to the objective need to strengthen the analytical nature of enterprise reports $[4,5]$. The study on the actual state of reporting of Ukrainian enterprises and proposals for supplementing existing reporting forms with information on environmental activities of the enterprise are given in [6]. Scientists identify the need to review the content of reporting for natural resource management and its importance for effective business development [7]. Disclosure of information on environmental and social performance of Romanian public interest entities has been studied in [8]. 
A number of scientists have conducted research in terms of finding areas for the integration of accounting, control and reporting [9]. A number of studies have been conducted to determine the value of disclosing information about the sustainability of corporate business through integrated reporting [10].

Information needs of stakeholders regarding the ecological state of natural resources and ecological responsibility formed in financial and non-financial indicators were studied in [11, 12]. The work [13] is devoted to the search for points of intersection of integrated reporting and accounting system of the business entity, which corresponds to the provisions of the concept of sustainable development. The analysis of the reasons for publishing information about the environmental activities of the business entity in its reporting is given in [14]. The authors surveyed the 100 best companies in the world for their compliance with the standards of the Global Reporting Initiative and the procedure for informing stakeholders.

The development of corporate social responsibility in Central and Eastern Europe is dealt with in [15, 16]. In addition, the author's vision of the social, ethical, environmental, cultural and historical contexts of the role of accounting is presented. The study on sustainability risks and their management within the management accounting and reporting is addressed in [17, 18].

Unsolved aspects of the problem. Unresolved issues remain regarding the composition of indicators that reflect the environmental condition of natural resources used in the activities of the entity in the non-financial statements of the enterprise.

Purpose. The research is aimed at developing a model of integrated reporting, which will assess the impact of the enterprise on natural resources and meet the information needs of stakeholders at the micro and macro levels.

Methods. The theoretical and methodological basis of the study are the fundamental provisions of modern economic theory, accounting theory and economic analysis, scientific developments of national and foreign scientists on non-financial reporting, greening and rationalization of environmental management. To achieve the goal of working and solving the tasks, the following research methods were used: abstract-logical, complex-system approach - in the study on the essence of non-financial reporting and identifying its features; causeand-effect relations - when developing a list of indicators of non-financial reporting on the environmental condition of natural resources in order to increase the relevance of information.

Results. For businesses seeking to operate on a sustainable basis, the development of integrated reporting on sustainable development is a topical issue in order to meet the information requests of interested users for a comprehensive assessment of businesses. Integrated reporting involves a combination of elements of financial and non-financial (contains information about the impact of the entity on the environment, society, economy) reporting. Financial and non-financial statements are always interconnected and complementary. But non-financial reporting is endowed with its characteristic features: it is concise and has a free form of presentation compared to financial one.

Every year in the business world, more and more companies, along with financial, publish non-financial reporting, which reflects the indicators of economic growth, social justice, and the company's efforts to ensure the integrity of the environment.

According to the integrated reporting, external users will be able to assess the investment attractiveness of the enterprise, the risk of investing in it, obtain information about the stability of the enterprise, its ability to fulfill contractual obligations, the company's ability to pay environmental tax and other obligations in order to protect the interests of users who are directly interested in the environmental activities of the enterprise, and so on. According to the research, $75 \%$ of global investment fund managers believe that indicators of sustain- able development of the company, its impact on the environment and society, have a direct impact on the investment attractiveness of the company [19]. Accordingly, the reporting of companies around the world is developing and in addition to financial indicators should provide stakeholders with comprehensive information on business results. This allows them to be more comprehensible and more transparent, and therefore more attractive to potential investors.

About $80 \%$ of public non-financial reports in the world are compiled using GRI standards. Of the 250 largest corporations in the world, $93 \%$ currently report their sustainability indicators and $82 \%$ use GRI standards for reporting [19].

In practice, reporting on sustainable development is still not widespread, although there is a growing trend each year in the number of companies reporting under the GRI (Fig. 1).

As for the enterprises of Ukraine, their activity in compiling reports according to GRI is insignificant but growing (Fig. 2).

The composition of non-financial reporting in Ukraine is determined mainly by company managers, who emphasize a number of problems: it is difficult for companies to determine and choose a system of voluntary reporting on sustainable development, because various prescriptions and initiatives are quite large, complex to implement and costly in terms of monitoring, collecting and processing information. However, the growing need for such information from users is forcing companies to prepare such reports. From the point of view of contractors and investors, business entities that openly provide information on social and environmental aspects of their activities are socially responsible. The costs of companies for the preparation of integrated reports are paid off by the loyalty of counterparties and creditors.

Thus, financial and non-financial reporting units form a single information base for the management of the enterprise, which seeks to comply with the provisions of the concept of sustainable development. Reports complement each other's information and are useful for both internal and external users.

According to the current methodological approach, natural resources as an object of accounting in Ukraine are reflect-

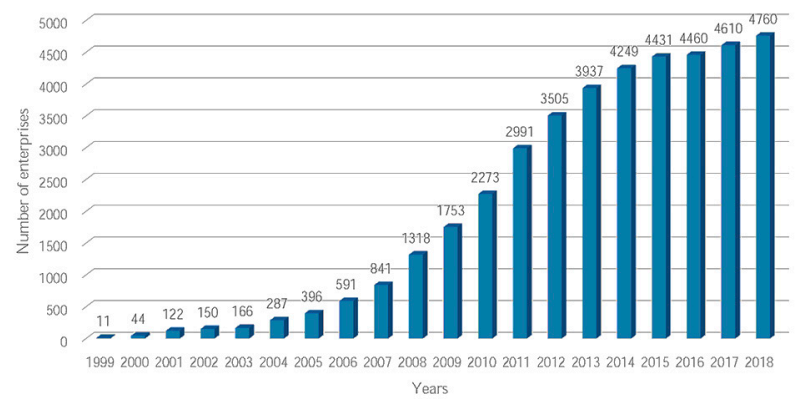

Fig. 1. Dynamics of the number of economic entities in the world that report according to GRI (developed by the authors on the basis of [20])

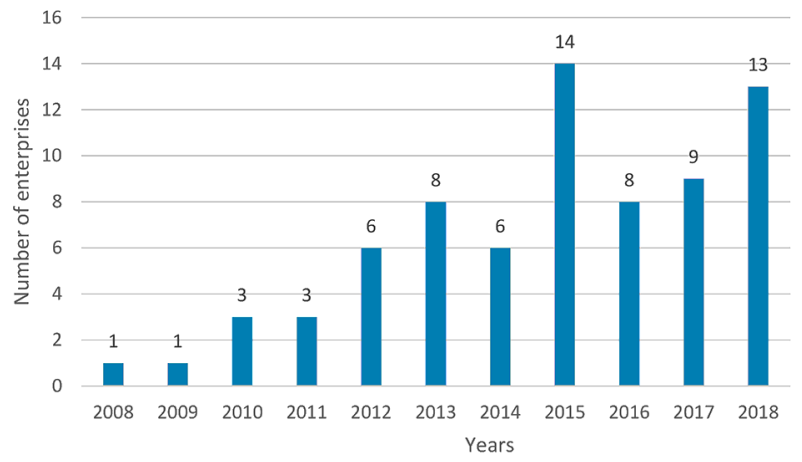

Fig. 2. Dynamics of the number of business entities of Ukraine that submit reports in accordance with GRI (developed by the authors on the basis of [20]) 
ed only in the financial statements, and environmental indicators are not reflected at all. Table 1 presents research on the reflection of natural resources in the financial statements of different countries.

Summarizing foreign and national experience in theoretical developments and current methodological support for the disclosure of information about natural resources and environmental indicators in the financial statements of the enterprise, we can conclude about the low level of generalization of such information. That is, nowadays the information support for the management of financial statements on natural resources is low. This state of information support is explained by the fact that these information data are summarized without proper separation and detail.

The result of this shortcoming is the fact that users of financial statements, who are interested in the use of natural resources, do not have the opportunity to use such information in making management decisions.

Therefore, we consider it appropriate in the management of natural resources and their environmental condition, to use the most integrated generalization of financial and non-financial indicators, which in the future will be an effective tool for decision-making and information base for developing and implementing strategic business projects. The result of the synergy of financial and non-financial information is integrated reporting, which summarizes information about the financial condition and results of financial and economic, social and environmental activities of the enterprise.

Synergy of integrated reporting leads to increasing its efficiency in management as a result of combining financial and non-financial indicators into a single information system.

The main purpose of integrated reporting in the management of the ecological state of natural resources is to provide reliable information about the comprehensive activities of the enterprise in accordance with the strategic objectives and management models. Such reporting should provide the following parameters:

1) satisfaction of the control system request;

2) a system of goals and tasks, the achievement and solution of which provides financial and non-financial information about natural resources and their ecological status.

The functions of integrated reporting will be as follows:

- it will combine financial and non-financial indicators of the ecological state of natural resources in one economic system;

- with its help there will be a creation of a modern information base for the management of the natural capital of the business and its ecological condition;

- it will provide a reorientation of the assessment of the effectiveness of business processes from short-term priorities to the establishment of the forecast efficiency of the enterprise;

- the formation of such reporting will be an additional factor in ensuring the growth of the value of national business.

Table 1

Reflection of natural resources in the financial statements of different countries

\begin{tabular}{|l|l|l|}
\hline Country & \multicolumn{1}{|c|}{$\begin{array}{c}\text { Name of the } \\
\text { reporting form }\end{array}$} & \multicolumn{1}{|c|}{$\begin{array}{c}\text { Sections and } \\
\text { reporting articles }\end{array}$} \\
\hline France & $\begin{array}{l}\text { Statement of financial } \\
\text { condition }\end{array}$ & $\begin{array}{l}\text { Real estate (including } \\
\text { natural resources) }\end{array}$ \\
\hline USA & $\begin{array}{l}\text { Statement of financial } \\
\text { condition }\end{array}$ & $\begin{array}{l}\text { Property (including } \\
\text { natural resources) }\end{array}$ \\
\hline Poland & Balance & Land \\
\hline $\begin{array}{l}\text { United } \\
\text { Kingdom }\end{array}$ & $\begin{array}{l}\text { Statement of financial } \\
\text { condition }\end{array}$ & $\begin{array}{l}\text { Tangible assets (including } \\
\text { land and buildings) }\end{array}$ \\
\hline Ukraine & $\begin{array}{l}\text { Balance Sheet (Statement } \\
\text { of Financial Position) }\end{array}$ & Non-current assets \\
\hline
\end{tabular}

Based on the global challenges of the modern world in the management of natural resources and their environmental condition, we propose a matrix of components of integrated reporting of business entities in terms of information about natural resources (Table 2).

The proposed matrix should become the basis for building an integrated reporting structure for business, as it takes into account the key needs of effective management of natural resources and their environmental condition.

Business entities, taking into account the above recommendations in the preparation of an integrated report should disclose financial and non-financial information so that users can comprehensivel y assess their activities in terms of the following aspects:

- the ability to achieve the planned strategic indicators of development;

- organization of enterprise management, its corporate culture;

- list of risks of the enterprise, their characteristics and outline ways to minimize them;

- operational and long-term plans for enterprise development;

- general information on the peculiarities of the enterprise;

- the main economic indicators of the enterprise;

- opportunities for further development, strategic goals, mission of the enterprise.

Based on this, a conceptual framework for integrated reporting to ensure the management of natural resources has been developed (Table 3 ).

Table 2

Matrix of components of integrated reporting to ensure the management of natural resources and their environmental condition

\begin{tabular}{|l|l|l|}
\hline $\begin{array}{c}\text { Accounting policy of } \\
\text { the integrated } \\
\text { accounting system }\end{array}$ & $\begin{array}{c}\text { Quality of } \\
\text { financial and } \\
\text { non-financial } \\
\text { information }\end{array}$ & $\begin{array}{c}\text { Meeting information } \\
\text { needs for } \\
\text { environmental } \\
\text { decision making }\end{array}$ \\
\hline $\begin{array}{l}\text { Estimation of future } \\
\text { costs in natural } \\
\text { resources } \\
\text { management and } \\
\text { environmental safety }\end{array}$ & $\begin{array}{l}\text { Modern tools for } \\
\text { natural resource } \\
\text { management and } \\
\text { environmental } \\
\text { safety }\end{array}$ & $\begin{array}{l}\text { Meeting information } \\
\text { needs for natural } \\
\text { resource } \\
\text { management }\end{array}$ \\
\hline $\begin{array}{l}\text { Balanced scorecard in } \\
\text { strategic management } \\
\text { of natural resources } \\
\text { and environmental } \\
\text { security }\end{array}$ & $\begin{array}{l}\text { Effective } \\
\text { management of } \\
\text { natural resources } \\
\text { and environmental } \\
\text { safety }\end{array}$ & Rising business \\
\hline
\end{tabular}

Table 3

Conceptual framework for integrated reporting to ensure natural resource management

\begin{tabular}{|l|l|}
\hline Components & \multicolumn{1}{|c|}{ Content } \\
\hline $\begin{array}{l}\text { Asking key } \\
\text { questions }\end{array}$ & $\begin{array}{l}\text { Defining the purpose and objectives of integrated } \\
\text { reporting in the sections of ecology and land } \\
\text { resources. Identification of information users }\end{array}$ \\
\hline Model & $\begin{array}{l}\text { Details, identification and disclosure of content, } \\
\text { description of the structure, key indicators, form of } \\
\text { presentation of information on natural resources }\end{array}$ \\
\hline $\begin{array}{l}\text { Capital } \\
\text { (resource) }\end{array}$ & $\begin{array}{l}\text { Financial, human, intellectual, natural and } \\
\text { social }\end{array}$ \\
\hline $\begin{array}{l}\text { Rising business } \\
\text { value }\end{array}$ & $\begin{array}{l}\text { Ensuring the growth of business value in the short, } \\
\text { medium and long term due to natural resources } \\
\text { and improving their environmental condition }\end{array}$ \\
\hline Risks & $\begin{array}{l}\text { Ways to minimize the risks that affect the } \\
\text { creation of business value through natural capital }\end{array}$ \\
\hline
\end{tabular}


Model of financial and non-financial indicators for management of natural resources and their ecological condition (on the example of land resources)

\begin{tabular}{|c|c|c|}
\hline Section & Composition and reporting elements & Characteristics of indicators \\
\hline \multicolumn{3}{|c|}{ Section 5. Land resources } \\
\hline \multirow[t]{2}{*}{5.1.} & \multicolumn{2}{|c|}{ Land resources for the intended purpose } \\
\hline & $\begin{array}{l}\text { Land use in agriculture; } \\
\text { Use of land for construction; } \\
\text { Protected lands; } \\
\text { Lands for health and tourism purposes; } \\
\text { Recreational lands; } \\
\text { Lands of historical and cultural purpose; } \\
\text { Land use in forestry; } \\
\text { Land of a water fund }\end{array}$ & $\begin{array}{l}\text { Information on land use of the agricultural enterprise during the reporting } \\
\text { year is provided. } \\
\text { The total area of agricultural land of the enterprise, which includes arable } \\
\text { land, fallow land, perennial plantations (orchards, berries, vineyards, and } \\
\text { so on., except for protected land), hayfields, grassland and pastures. } \\
\text { Balance at the beginning of the year (initial (revalued) cost); Increased by } \\
\text { a year; Revaluation (mark up +, mark down -); Decreased by a year; } \\
\text { Impairment losses; Other changes for the year; Balance at the end of the } \\
\text { year (initial (revalued) cost) }\end{array}$ \\
\hline \multirow[t]{2}{*}{5.2} & \multicolumn{2}{|c|}{ Sources of income to the enterprise of land resources } \\
\hline & $\begin{array}{l}\text { Land resources were purchased for cash; } \\
\text { Land resources are included in the authorized capital; } \\
\text { Land resources received under the exchange contract; } \\
\text { Land received free of charge: } \\
\text { - land easement; } \\
\text { - land superficies; } \\
\text { - land emphyteusis. } \\
\text { Land resources are obtained as security for obligations; } \\
\text { Land resources are acquired on the rights of use }\end{array}$ & $\begin{array}{l}\text { The sources of income to the enterprise of land resources are reflected. } \\
\text { Name of legal or natural person, his id. code, legal address, managers and } \\
\text { final beneficiary. The plan of agricultural activity on the land plot which } \\
\text { the subject has expressed desire to acquire }\end{array}$ \\
\hline \multirow[t]{2}{*}{5.3} & \multicolumn{2}{|c|}{ The right to use the land } \\
\hline & $\begin{array}{l}\text { Land resources on the rights of permanent use; } \\
\text { Land resources on the rights of temporary use; } \\
\text { Leased land resources; } \\
\text { Land resources in sublease; } \\
\text { Land resources are acquired by easement; } \\
\text { Land resources are acquired on the rights of superficies; } \\
\text { Land resources are acquired on the rights of } \\
\text { emphyteusis; } \\
\text { Cost of permanent land use rights and } \\
\text { The cost of rental rights }\end{array}$ & $\begin{array}{l}\text { Summarizes information on the value of permanent land use rights, the } \\
\text { value of lease rights and other rights (emphyteusis and superficies). } \\
\text { The amount of payment for the use of land on lease and sublease rights is } \\
\text { reflected. } \\
\text { The cost of initial recognition; Quantitative value of the indicator; Result } \\
\text { from use in economic activity; Qualitative parameters of the indicator; } \\
\text { The useful life of the asset; Counterparty; Suitability, and so on }\end{array}$ \\
\hline \multirow[t]{4}{*}{5.4} & \multicolumn{2}{|r|}{ Ownership documents } \\
\hline & Ownership of land resources & $\begin{array}{l}\text { Certificate of ownership of immovable property; Extract from the State } \\
\text { Register of Real Property Rights on registration of ownership; Contract } \\
\text { of sale Certificate of inheritance }\end{array}$ \\
\hline & The right of permanent use of land & State act on the right of permanent use of land \\
\hline & The right of temporary use of land & $\begin{array}{l}\text { Agreement on the right of temporary use of land (including land lease } \\
\text { agreement), superficies agreement }\end{array}$ \\
\hline \multirow[t]{2}{*}{5.5} & \multicolumn{2}{|c|}{ Use of land resources in the reporting period } \\
\hline & $\begin{array}{l}\text { Land purchase and sale agreements; } \\
\text { Land use (lease) agreements }\end{array}$ & $\begin{array}{l}\text { - the number of concluded contracts of sale of land, pcs.; } \\
\text { - area of land plots acquired during the reporting period, thousand } \\
\text { hectares; } \\
\text { - area of land sold during the reporting period, thousand hectares; } \\
\text { - cost of land acquisition, thousand UAH; } \\
\text { - cost of land sales, thousand UAH; } \\
\text { - the number of concluded land use agreements, pcs.; } \\
\text { - cost of land use agreements, thousand UAH }\end{array}$ \\
\hline \multirow[t]{2}{*}{5.6} & $\begin{array}{l}\text { Volumes of capital investments in land plots and rights } \\
\text { to use them }\end{array}$ & $\begin{array}{l}\text { Generalization of information on investments for the acquisition of land } \\
\text { in accordance with current legislation and the acquisition of natural } \\
\text { resources for the subsequent production of oil, gas, etc. } \\
\text { Investments in the acquisition of land for the construction of new } \\
\text { buildings and structures, housing under construction for resale (transfer) } \\
\text { and taking into account costs that do not belong to the capital investment } \\
\text { of the reporting unit }\end{array}$ \\
\hline & \multicolumn{2}{|c|}{ Section 6. Environmental responsibility } \\
\hline 6.1. & Ecological culture of production processes & $\begin{array}{l}\text { Ecology of production processes; innovative environmental projects into } \\
\text { production; pollution prevention; sustainable use of land resources; } \\
\text { environmentally friendly products; environmental management }\end{array}$ \\
\hline 6.2 & Environmental activities & $\begin{array}{l}\text { Environment; protection and restoration of the natural environment; } \\
\text { efficient use of land resources; costs of improving land resources }\end{array}$ \\
\hline
\end{tabular}


We consider it expedient to display the following objects of natural resources in the system of integrated reporting:

1. Non-agricultural land plots as the main asset on property rights, which is an asset of the enterprise and investment real estate.

2. Agricultural land as a form of rights to use it, which are considered as: intangible asset on the rights of use; object of accounting of lease relations.

It is impossible to implement any management decision on the rational use of natural resources without attracting investment. Therefore, bioresource management is an innovation and investment function. Efficient use of natural resources is possible only on the basis of investment and innovation programs.

Taking into account the above considerations regarding the management of land capital and financial and economic activities of companies, a model of financial and non-financial indicators for managing natural resources and their environmental condition (on the example of land resources) is proposed (Table 4).

The proposed structure of indicators of integrated reporting combines the main components of financial, tax, statistical, internal, social reports. The structure of such reporting will depend on the needs of the land management system, the requirements of society and government agencies and the business model.

The advantages of using this form of report are:

- obtaining the necessary information for decision-making in land management;

- ensuring the comparability of information between different enterprises while taking into account the specifics of the industry;

- ensuring investment attractiveness, which in the future will help attract foreign investment and loans, as well as access to foreign markets;

- achieving transparency of information, ensured by compliance with the basic principles of accounting.

In the reports characterizing the financial condition of enterprises of developed world countries, information on the movement of land capital is reflected in separate articles and takes up to $40 \%$ in the structure of assets.

It is possible to increase the reliability of non-financial reporting by obtaining information from accounting, which in its objects has those that reflect natural resources and their environmental condition. Basing on the information from the accounting system, each company will be able to regularly form the appropriate section of non-financial reporting. The information obtained on the basis of accounting data based on the principles of sustainable development will meet the requirements of the Management Report on Sustainable Development, and will allow fully assessing the responsibility of enterprises to society, employees and shareholders.

Conclusions. Thus, the result of the study is a scientific and methodological approach to the implementation of integrated reporting in the practice of agrarian enterprises. The integration of financial and non-financial reporting on natural resources and their environmental status will create a single information base for the management of natural capital and the activities of enterprises.

The proposed format of the structure and content of integrated reporting in terms of natural resources, in the result of which there is reliable, clear and comparable information that will provide a comprehensive analysis of the enterprise and the development on its basis of sound management and control decisions. In the process of integration, non-financial reporting will be supplemented by a number of financial indicators that will be compatible with each other, which will help to ensure high quality decisions.

Therefore, the proposed integrated reporting will not violate legal rights, commercial obligations, privacy of business owners and will create favorable conditions for effective man- agement of natural resources and their environmental condition.

Implementation of the proposals will allow: at the level of business entities - forming timely, reliable and adequate to the needs of management information on environmental activities of the enterprise, which will be the basis for sound management decisions in regulating environmental impact and ensure rational use of natural resources as a basis of national wealth Ukraine; at the state level -obtaining reliable consolidated statistical information that will ensure the validity of state environmental policy, increase the interest and confidence of external users in information about the activities of national enterprises considering their impact on natural resources, restore the ecological and economic balance in the country.

\section{References.}

1. Strategy for improving the management mechanism in the field of use and protection of state-owned agricultural lands and their disposal: Resolution of the Cabinet of Ministers of Ukraine of 07.06.2017 No. 413. Official Gazette of Ukraine. No. 51. (2017). 2. Bilan, Y., Zos-Kior, M., Nitsenko, V., Sinelnikau, U., \& Ilin, V. (2017). Social component in sustainable management of land resources. Journal of Security and Sustainability Issues, 7(2), 107-120. https://doi.org/10.9770/jssi.2017.7.2(9).

3. Nitsenko, V., Chukurna, O., Mardani, A., Streimikis, J., Gerasymchuk, N., Golubkova, I., \& Levinska, T. (2019). Pricing in the Concept of Cognitive Marketing in the Context of Globalization: Theoretical, Methodological and Applied Aspects. Montenegrin Journal of Economics, 15(4), 131-147. https://doi.org/10.14254/1800-5845/2019.15-4.10.

4. Bezdushna, Y., Zhuk, V., \& Tyvonchuk, S. (2019). Improvement of IFRS application policy in relation to land assets of agricultural enterprises. Independent journal of management $\&$ production (IJM\&P), 10(7), 702-724. https://doi. org/10.14807/ijmp.v10i7.889.

5. Zamula, I. (2016). Profitability analysis for eco-friendly products within marketing research. Actual problems of the economy, 8(179), 317-322.

6. Tanasiieva, M., Travin, V., Zamula, I., Nitsenko, V., Balezentis, T., \& Streimikiene, D. (2020). Assessment of the Profitability of Environmental Activities in Forestry. Sustainability, 12(7), 2998. Retrieved from https://www.mdpi.com/2071$1050 / 12 / 7 / 2998$.

7. Sokil, O., Valeriy, Z., Holub, N., \& Levchenko, O. (2019). Accounting and Analytical Methods for Identifying Risks of Agricultural Enterprises' Sustainable Development. In: Nadykto, V. (Ed.) (2019). Modern Development Paths of Agricultural Production. Cham: Springer. https://doi.org/10.1007/978-3030-14918-5 55.

8. Dobre, E., Stanila, G. O., \& Brad, L. (2015). The Influence of Environmental and Social Performance on Financial Performance: Evidence from Romania's Listed Entities. Sustainability, 7(3), 2513-2553; https://doi.org/10.3390/su7032513. 9. Vitale, G., Cupertino, S., Rinaldi, L., \& Riccaboni, A. (2019). Integrated Management Approach Towards Sustainability: An Egyptian Business Case Study. Sustainability, 11(5), 1244. https://doi.org/10.3390/su11051244.

10. Camodeca, R., Almici, A., \& Sagliaschi, U. (2018). Sustainability Disclosure in Integrated Reporting: Does It Matter to Investors? A Cheap Talk Approach. Sustainability, 10(12), 4393. https://doi.org/10.3390/su10124393.

11. Sokil, O. G., Zhuk, V. M., \& Vasha, L. (2018). Integral assessment of sustainable development of agriculture in Ukraine. Economic Annals-XXI, 170(3-4), 15-21. https://doi. org/10.21003/ea.V170-03.

12. Zamula, I. (2015). Accounting component of environmental obligations management in accordance with the principles of sustainable development. Actual problems of the economy, 4(166), 261-267.

13. Atağan, G. (2017). Sustainability Reporting Versus Integrated Reporting: BIST Sustainability Index. New Trends in 
Finance and Accounting. Retrieved from https://www.researchgate.net/publication/312272375_Sustainability_Reporting_Versus_Integrated_Reporting_BIST_Sustainability Index.

14. Bednárová, M., Klimko, R., \& Rievajová, E. (2019). From Environmental Reporting to Environmental Performance. Sustainability, 11(9), 2549. https://doi.org/10.3390/su11092549.

15. Zyznarska-Dworczak, B. (2018). The Development Perspectives of Sustainable Management Accounting in Central and Eastern European Countries. Sustainability, 10(5), 1445. https://doi.org/10.3390/su10051445.

16. Abad-Segura, E., Joaquín Cortés-García, F., \& BelmonteUreña, L.J. (2019). The Sustainable Approach to Corporate Social Responsibility: A Global Analysis and Future Trends. Sustainability, 11(19), 5382. https://doi.org/10.3390/su11195382.

17. Truant, E., Corazza, L., \& Scagnelli, S. D. (2017). Sustainability and Risk Disclosure: An Exploratory Study on Sustainability Reports. Sustainability, 9(4), 636. https://doi. org/10.3390/su9040636.

18. Bilan, Y., Nitsenko, V., Ushkarenko, I., Chmut, A., \& Sharapa, O. (2017). Outsourcing in international economic relations. Montenegrin Journal of Economics, 13(3), 175-185. https://doi.org/10.14254/1800-5845/2017.13-3.14.

19. Ukrenergo has published a report on sustainable development in 2018 (2019). Retrieved from https://ua.energy/osnovnipodiyi/ukrenergo-opublikuvalo-zvit-zi-stalogo-rozvytku-zarezultatamy-2018-roku/.

20. Reporting in the field of sustainable development GRI (n.d.). Retrieved from https://bakertilly.ua/news/id40621.

\section{Показники екологічного стану природних ресурсів в інтегрованій звітності підприємства}

\section{I. В. Замула ${ }^{1}$, М. А. Проданчук $\kappa^{2}$, Т. М. Ковальчук ${ }^{3}$,} О. М. Колеснікова ${ }^{4}$, A. А. Михалків ${ }^{3}$

1 - Державний університет «Житомирська політехніка», м. Житомир, Україна, e-mail: zamula@ztu.edu.ua

2 - Національний науковий центр «Інститут аграрної економіки», м. Київ, Україна

3 - Чернівецький національний університет імені Юрія Федьковича, м. Чернівці, Україна

4 - Національний університет біоресурсів і природокористування України, м. Київ, Україна

Мета. Дослідження спрямовано на розробку моделі інтегрованої звітності, що дозволить оцінити вплив підприємства на стан природних ресурсів і задовольнити інформаційні запити стейкхолдерів мікро- й макрорівнiв.

Методика. Теоретичною й методологічною основою дослідження є фундаментальні положення сучасної економічної теорії, теорії бухгалтерського обліку та економічного аналізу, наукові розробки вітчизняних і закордонних учених із проблем нефінансового звітування, екологізації й раціоналізації природокористування. Для досягнення мети роботи використані такі методи дослідження: абстрактно-логічний, комплексно-системний підходи - при дослідженні сутності нефінансового звітування та виявленні його особливостей; причинно-наслідкових зв'язків - при розробці переліку показників нефінансової звітності щодо екологічного стану природних ресурсів 3 метою підвищення релевантності інформації.

Результати. Запропонована структура та зміст інтегрованої звітності в частині природних ресурсів та їх екологічного стану, результатом формування якої є достовірна, зрозуміла й зіставна інформація, що забезпечить можливість усебічного аналізу діяльності підприємства та розробки на його основі виважених управлінських і контрольних рішень. У процесі інтеграції нефінансова звітність доповнить фінансову низкою показників, які будуть сумісними між собою, що сприятиме забезпеченню високої якості прийнятих рішень. Запропонована інтегрована звітність не порушуватиме юридичних прав, комерційних зобов'язань, недоторканності приватного життя власників бізнесу та створить сприятливі передумови для ефективного управління природними ресурсами та їх екологічним станом.

Наукова новизна. Результатом проведеного дослідження $є$ розроблений науково-методичний підхід до впровадження у практичну діяльність підприємств інтегрованої звітності. Інтеграція фінансової й нефінансової звітності щодо природних ресурсів та їх екологічного стану створить єдину інформаційну базу для управління природним капіталом і діяльністю підприємств.

Практична значимість. Упровадження пропозицій дозволить: на рівні суб'єктів господарювання - формувати своєчасну, достовірну та адекватну потребам управління інформацію щодо екологічної діяльності підприємства, що буде основою прийняття виважених управлінських рішень у сфері регулювання впливу на навколишнє природне середовище й гарантуватиме раціональне користування природними ресурсами як основи національного багатства України; на рівні держави отримувати достовірну зведену статистичну інформацію, що забезпечуватиме обгрунтованість формування державної екологічної політики, підвищуватиме інтерес і довіру зовнішніх користувачів до інформації про діяльність вітчизняних підприємств з огляду на їх вплив на природні ресурси, відновлюватиме еколого-економічний баланс у країні.

Ключові слова: інтегрована звітність, нефінансова інформація, управління природними ресурсами, екологічна відповідальність, соціальна відповідальність бізнесу

\section{Показатели экологического состояния природных ресурсов в интегрированной отчетности предприятия}

\section{И. В. Замула , М.А. Проданчук $\kappa^{2}$, Т. Н. Ковальчук ${ }^{3}$, О. Н. Колесникова ${ }^{4}$, А. А. Михалкив ${ }^{3}$}

1 - Государственный университет «Житомирская политехника», г. Житомир, Украина, e-mail: zamula@ztu.edu.ua 2 - Национальный научный центр «Институт аграрной экономики», г. Киев, Украина

3 - Черновицкий национальный университет имени Юрия Федьковича, г. Черновцы, Украина

4 - Национальный университет биоресурсов и природопользования Украины, г. Киев, Украина

Цель. Исследование направлено на разработку модели интегрированной отчетности, которая позволит оценить влияние предприятия на состояние природных ресурсов и удовлетворить информационные запросы стейкхолдеров микро- и макроуровня.

Методика. Теоретической и методологической основой исследования являются фундаментальные положения современной экономической теории, теории бухгалтерского учета и экономического анализа, научные разработки отечественных и зарубежных ученых по проблемам нефинансовой отчетности, экологизации и рационализации природопользования. Для достижения цели работы использованы следующие методы исследования: абстрактно-логический, комплексно-системный подход - при исследовании сущности нефинансовой отчетности и выявлении ее особенностей; причинно-следственных связей - при разработке перечня показателей 
нефинансовой отчетности по экологическому состоянию природных ресурсов с целью повышения релевантности информации.

Результаты. Предложена структура и содержание интегрированной отчетности в части природных ресурсов и их экологического состояния, результатом формирования которой является достоверная, понятная и сопоставимая информация, которая обеспечит возможность всестороннего анализа деятельности предприятия и разработки на его основе взвешенных управленческих и контрольных решений. В процессе интеграции нефинансовая отчетность дополнит финансовую рядом показателей, которые будут совместимыми между собой, что будет способствовать обеспечению высокого качества принимаемых решений. Предложенная интегрированная отчетность не будет нарушать юридических прав, коммерческих обязательств, неприкосновенности частной жизни владельцев бизнеса и создаст благоприятные предпосылки для эффективного управления природными ресурсами и их экологическим состоянием.

Научная новизна. Результатом проведенного исследования является разработанный научно-методический подход к внедрению в практическую деятельность предприятий интегрированной отчетности. Интеграция финансовой и нефинансовой отчетности по природным ресурсам и их экологическому состоянию создадут еди- ную информационную базу для управления природным капиталом и деятельностью предприятий.

Практическая значимость. Внедрение предложений позволит: на уровне субъектов хозяйствования - формировать своевременную, достоверную и адекватную потребностям управления информацию об экологической деятельности предприятия, будет основанием для принятия взвешенных управленческих решений в сфере регулирования воздействия на окружающую среду и гарантировать рациональное пользование природными ресурсами как основы национального богатства Украина; на уровне государства - получать достоверную сводную статистическую информацию, которая будет обеспечивать обоснованность формирования государственной экологической политики, повышать интерес и доверие внешних пользователей к информации о деятельности отечественных предприятий с учетом их влияние на природные ресурсы, восстанавливать эколого-экономический баланс в стране.

Ключевые слова: интегрированная отчетность, нефинансовая информация, управление природными ресурсами, экологическая ответственность, социальная ответственность бизнеса

Recommended for publication by O.M. Petruk, Doctor of Economic Sciences. The manuscript was submitted 08.06.20. 